\title{
A Review of Quality Education in Bangladesh
}

\author{
S M Tazuddin, Assistant professor and Head of the Department, \\ Dept.Business Adminitrations ,Cantonment College Jashore, Bangladesh.
}

\begin{abstract}
Education is the most powerful weapon we can use to change the world and for self-enlightenment. The study is mainly based on theoretical approach and secondary data have been used. This paper is particular focus on understandings of education and quality education in Bangladesh. The paper identifies six crucial dimensions of quality education that are recurring themes of debate on quality. This study however is aimed at showcasing the importance of quality education that meet the human needs, social, community or country needs and market demand also with relevant qualifications for the suitable job. Furthermore this research seeks to explore some barriers and recommendations provide quality education basing on the perspective in Bangladesh.
\end{abstract}

Keywords:- Education, quality-education, crucial dimensions, fundamental principles, barriers and sustainability.

\section{INTRODUCTION}

No matter how we define quality education, its features or dimensions may not be able to keep pace with the contemporary education system. From education policy researchers to policy presenters, policy makers, education administration policy implementers, political leaders and Head of the state, as well as those of us who are somehow connected to the education system. The urgent necessity of an all - encompassing beautiful combination system is the demand of the time now. Because if we can't do that, then the way our country is going today, from economically underdeveloped countries to developing countries and step by step from middle Income countries, may be one day we will be able to be develop country. But failure to ensure quality education leaves much doubt as to whether the development will be sustainable or not. To ensure quality education is a must.

In this context, I would like to mention the quota at the entrance of south African University, there is no need to drop an atomic bomb to destroy a country or a nation. The only thing that needs to be done is to give the students of that country a chance to cheat in the exam hall. Then the doctors who publish his output will kill people. The bridge, culvert built by the engineer will collapse. The country's economy will be bankrupted by the economists, the judge will establish injustice, and then country or nation will completely be destroyed.

Quality education has an important role both for the student, as an individual, and also for the society in which he lives. Quality education represents an aid for the growth and the development of the students and a key for a better life. For the society, quality education institutions can contribute to the creation of ideal citizens, who will help in keeping the society peaceful. 'Education is one of the basic needs for human development and to escape from poverty' (Sivakumar \& Sarvalingam, 2010), it is necessary for national development and a prosperous society. According to Rahman and Uddin (2009) education is the responsibility of the government and should be managed through national resources. Most of the educationists claim that curricular, resources, text books, social linguistics and social values of the local communities and encouragement of the ethnic minorities may be focused to improving the quality education in schools.

When the quality of teachers is maintained the quality education can be expected in schools. The quality of teacher with indicators may reflect the quality of schools. Addition to this some factors of quality education are required like curriculum, planning, transformation of curriculum, infrastructural development, learning resources, student participation and organization and management. After reviewing the literature, we find that the quality of education cannot be uniquely defined, but the theorists, practitioners and trainees agree that the fundamental and the most important purpose of education at all levels is quality of teaching and learning process and achievements (knowledge) of students (Brejc, Sirok \& Juric Rajh, 2008).

But it should be noted that focusing exclusively on the cognitive performance of students also means the impoverishment of the mission of the school, as the effects of schooling are more complex and cover many areas of human activity (Cankar, 2009). By Brejc, Sirok \& Juric Rajh (2008) the effectiveness is defined as extent to which the performance is achieved compared with planned results and with program and administration costs. According to Creemers \& Kyriakides (2008, in Cankar, 2009) in the history of educational effectiveness research we can trace economical, sociological and pedagogical-psychological line.

\section{THEORETICAL FRAMEWORK}

\section{A. Education:}

Education is the general sense to acquire knowledge or skills. Education is the process of acquiring knowledge systematically in a broad sense. However, education is a continuous practice for full development. The word Bengali education comes from the root "shas" which means "to rule" or "give advice". The English word education, on the other hand, comes from the Latin word "educare" which means bring out the inside. Education in the language of socrates is the eradication of falsehood and the development of truth. Aristotle said that education is to create a healthy mind in a healthy body. Education is in the language of Rabindranath Tagore, so those who not only 
serve information the world build our lives in harmony with honesty.

\section{B. Quality education:}

We need to have some decisions about what type of education to take and how to take it. In fact, it is difficult to define quality education in one word. Different academics have defined the subject in different ways. However, some issues are common to everyone's Opinion, and through them we can tell what quality education really is. Basically, quality education is a set of subjects that are only a part of the results of public examinations. Therefore, we cannot say that getting higher grade in public examination is quality education. A good quality education is one that provides all learners with capabilities they require to become economically productive, develop sustainable livelihood, contribute to peaceful and democratic societies and enhance individual well- being.

\section{Six crucial dimensions of quality education:}

$>$ Equity: Equity means the equality being fair or impartial. Equality means education for all. Gender, family status, tribal identity, personal and social conditions are not barriers to achieve humid potential. Every person can get minimum level of skill.

$>$ Child friendly teaching and learning: Quality education should be child friendly teaching and learning. Quality education puts a child at a central point and helps him reach his a chance great position in future.

$>$ Sustainability: Sustainability focuses on meeting the present needs without compromising the ability of future generation to meet their needs. It takes time to adopt the process of change in education. This process will be possible institutionalised by increasing the power of local authorities.

$>$ Balanced approach: The aim of quality education is to establish a peaceful and democratic society. Students are able to earn a sustainable livelihood in social and economically productive sector and that is in need of personal well -being.

> Contextualization and relevance: Quality education does not depend on a specific subject matter that is apposite or relevant in situation. The solution and adaptation of education system must be based on human needs, social, community or country needs.

$>$ Learning outcomes: Students to achieve minimum level of qualifications after taking education at a certain stage. Quality education requires results oriented progress.

\section{METHODOLOGY}

The paper is mainly based on theoretical approach. Both primary source and secondary source have been used in the study. The primary data collected by using survey method. And secondary data collected from journal, published report, various books and internal article. A brief literature review was conducted for identifying the studies that are associated with analysis of educational quality.

\section{OBJECTIVES}

The objectives of the study are:

To know the quality education and its six crucial dimensions

To find out barriers of quality education

$>$ To give some suggestion and recommendation to overcome its barriers.

\section{FUNDAMENTAL PRINCIPLES}

Quality education is a dynamic concept that depends on human needs, socio economic and environmental factors.

$>$ The goal of education is far beyond achieving numerical literacy and literacy skills. Basic skill including life skills such as responsibility, critical thinking, creative talent, and ability to make well balanced decision and enrich itself.

$>$ Curriculum teaching elements and teaching methods must meet the education goals as defined by international law.

$>$ There should be suitable classroom accessibility to all with adequate and separate sanitation facilities for girls and boys.

$>$ The material conditions of the teaching staff will be continuously improved. The institution should have a sufficient number of trained teachers to receive quality services and ample trainings on gender sensitivity, nondiscrimination and human rights issue.

$>$ Everyone has the right to a quality education. States must ensure equal quality education in all public schools of the same level.

$>$ Quality education requires human and financial resources as much as possible.

$>$ The child's right to leisure activities, recreational activities, cultural life and art.

\section{BARRIERS TO QUALITY EDUCATION}

Primary education, secondary education, College education, madrasa education, vocational education, there are currently 1 lakh 62 thousand 512 educational institutions in the country for technical education and University education which is not less than the need.( BANBEIS - 2015). Adequate number of educational institutions build physical infrastructure development and modernization education up to class XII the number of unpaid education and scholarship has multiplied. The unprecedented importance of computer and modern science and information communication technology is visible but the quality of education is not. The reasons are manifold.

\section{The following reasons are revealed:}

$>$ Quality teaching requires talented, highly educated, trained and skilled experienced innovative teachers. There is a huge shortage of quality teachers in private schools, Colleges, madrasas and technical education Institutions. 
Due to the obscurity of the Managing committee and the governing body, qualified and meritorious teachers are not being appointed. Although the board of recruitment has expert representatives from the Department of secondary, and higher education and the board of education of the national University, recruitment system is ambiguous. Although the current national teacher registration and certification authority has been assigned the task of selecting teachers, the recruitment process is being delayed due to bureaucratic complications.

$>$ The reality of curriculum implementation in secondary schools is essential to have subject based teachers. The shortage of secondary school teachers is evident in the complexity of the manpower structure, mathematics is taught by Bengali teachers and subject of religion, science and business are taught by English teachers. As a result, quality learning is still a nightmare.

$>$ The formation of the managing committee and the governing body as a party has created factionalism and rivalry between the parents, teacher and students, disrupting the discipline of the Institution and disrupting the learning environment.

$>$ Teachers in schools, colleges, madrasas and technical education institutions are responsible for $97 \%$ of education. And government teachers are responsible for only $3 \%$ of education. As a result, teaching learning has been adversely affected due to resentment and disgust among the majority of teachers.

$>$ Shortage of teachers in government Schools and Colleges could not ensure the quality education. The shortage of teacher is high outside the capital and departmental and larger districts. There is no separate cadre in education administration and management level though they are working on deputation in the Department of education, Board of education, Textbook board, NAEM etc. As a result there is vacuum in teaching learning activities.

$>$ Teacher training is undeniable for ensuring quality teaching. The shortage of teachers is noticeable in many schools. Failure to compile part time teacher during training is creating a vacuum of teaching learning.

$>$ Although English is a foreign language, its importance is immense. The shortage of English teacher is huge. So it is not possible to ensure quality education.

$>$ Due to the lack of suitable science teachers and libraries, the number of science students is declining day by day.

In order to achieve quality in teaching learning, the above mentioned problems must be solved. The importance of secondary education after primary education is acknowledged. If there is public private inequality in secondary education quality, quality will not be achieved. There is no substitute for quality teaching for quality learning. In order to ensure quality teaching, qualified and meritorious teachers must be recruited. Meritorious people will not be attracted to teaching if there is in equality between government and private sector. Therefore, secondary education like primary education should be brought under nationalization. Only then the quality of learning quality will be ensured by the teaching quality.

\section{RECOMMENDATIONS AND CONCLUSION}

But there has been very little research and experimentation policy on our education system. But somewhere there seems to be a slight deviation or fall of rhythm. There are thousands of GPA five but only $2 \%$ pass in the admission test such problems are also visible. Some steps can be taken in the midst of hundreds of limitations that can help improve the quality of education:

$>$ Our previous generation was formed under the leadership of those who will build the present and future generation but they are none other than me, you and a large community like us. The nation builder depends on us as we can build a nation with advanced human values.

$>$ As a teacher, our main responsibility is to teach in the classroom. Class conduction becomes lively if we prepare ourselves well for the class.

$>$ We need to be as caring for our students as we are for our own children.

$>$ If the teachers prepare the question papers of the internal examinations of the school and College themselves, the skills of the teachers will increase.

$>$ Specific subject teacher should be taken his subject oriented class. It is natural that a math class will not be very effective for a teacher who has passed from history.

$>$ In order to develop the students as a full-fledged human being, they have to develop their habit of reading books, wall magazine, weekly and monthly, magazine along with textbooks in the educational institutions every year.

$>$ Co-curriculum activities should be prioritized in order to make the students enlightened both in body and soul.

$>$ There is a need to introduce standards and board of Directors system in private educational institutions.

$>$ We need to ensure that our students are truly evaluated in all areas. Care should be taken so that he is not overvalued and undervalued again.

\section{$>$ Conclusion:}

Education is the backbone of a nation but it should be quality education. The importance of quality education can be judged from the way it benefits a person financially, emotionally, socially, as well as intellectually. Above all, if we can build ourselves as human beings with human values, we can be the idols to our students and the quality of education will improve. The number of people with advanced human values will increase in the country. The country will be more developed and the development of the country will be sustainable. Only then will we find enlightened people, enlightened world. 


\section{REFERENCES}

[1]. UNICEF (2000). Curriculum report card. Working Paper Series, Education Section, Programme Division. New York, NY: Author.

[2]. Sarpkaya, R. (2010). Factors affecting individual education demand at the entrance to university: Adnan menderes university sample. Educational Sciences: Theory and Practice, 10(1), 475-488.

[3]. Sivakumar, M., \& Sarvalingam, A. (2010). Human deprivation index: A measure of multidimensional poverty.

[4]. Rahman, A. U., \& Uddin, S. (2009). Statistical analysis of different socio economic factors affecting education of NW. FP (Pakistan). Journal of Applied Quantitative Methods, 4(1), 88-94.

[5]. Adina-Petruţa PAVEL, (2012), The Importance of Quality in Higher Education in an Increasingly Knowledge-Driven Society, International Journal of Academic Research in Accounting, Finance and Management Sciences, Vol-2, no-1, pp-120-127.

[6]. Militaru, C., Pavel, A.P., (2012), The Bologna Process and its implications on the European Higher Education in Romanian Statistical ReviewSupplement, pp. 199-206.

[7]. Adams, D. (1993). Defining educational quality, Improving Educational Quality, Project Publication\# 1: Biennial Report. Arlington, VA: Institute for International Research.

[8]. Anderson, S. E. (2000, March). A coordinated district consultant/teacher centre approach to school-based teacher development: The Mombasa School Improvement Project. In Annual Meeting of the Comparative and International Education Society, San Antonio, Texas.

[9]. Brandt, R. S. (2000). Education in a New Era. 2000 ASCD Yearbook. Association for Supervision and Curriculum Development, 1703 N. Beauregard St., Alexandria, VA 22311-1714.

[10]. Bailey, A. R., Chow, C. W., \& Haddad, K. M. (1999). Continuous improvement in business education: Insights from the for-profit sector and business school deans. Journal of Education for Business, 74(3), 165180.

[11]. Bay, A. (1999). Balancing theory and practice in teaching. Retrieved from http://core.journals.yorku.ca/ index.php/core/article/view/2724/1929

[12]. Bertolin, J. C. G. (2011). The quasi-markets in higher education: From the improbable perfectly competitive markets to the unavoidable state regulation. Educação e Pesquisa, 37(2), 237-248.

[13]. Brennan, J., \& Teichler, U. (2008). The future of higher education and of higher education research. Higher Education, 56(3), 259-264.

[14]. Briukhanov, V., Kiselev, V., Timchenko, N., \& Vdovin, V. (2010). Monitoring the opinions of parents of college students as a component of the institution's In-house education quality management system. Russian Education \& Society, 52(5), 79-88.
[15]. Buchanan, J. (2011). Quality teaching: Means for its enhancement? Australian Universities' Review, 53 (1), 66-72. 